\title{
The HIV epidemic in Jamaica: a need to strengthen the National HIV Program
}

\author{
J. Peter Figueroa ${ }^{1}$, Jacqueline P. Duncan ${ }^{1}$, Althea Bailey ${ }^{1}$, and Nicola Skyers ${ }^{2}$
}

Suggested citation Figueroa JP, Duncan JP, Bailey A, Skyers N. The HIV epidemic in Jamaica: a need to strengthen the National HIV Program. Rev Panam Salud Publica. 2020;44:e157. https://doi.org/10.26633/RPSP.2020.157

ABSTRACT Objectives. To assess the status of the HIV epidemic and programmatic implementation in Jamaica while identifying strategies for achieving effective HIV control.

Methods. The assessment included a review of the core indicators of the UNAIDS Global Monitoring Framework, a desk review of program reports, and unstructured interviews of stakeholders.

Results. HIV prevalence among adults in Jamaica was 1.5\% in 2018 with an estimated 32617 persons living with HIV (PLHIV) and 27324 persons (83.8\%) diagnosed with HIV; 12711 (39.0\% of all PLHIV or 46.5\% aware of their status) were on anti-retroviral therapy (ART) in the public health sector and $61.8 \%$ PLHIV on ART were virally suppressed. HIV prevalence among men who have sex with men remains high $(31.4 \%$ in $2011,29.6 \%$ in 2017 ) but has declined among female sex workers (12\% in 1990, $2 \%$ in 2017). HIV prevalence among public sexually transmitted infection clinic attendees, prison inmates and the homeless has increased in recent years. During 2018 approximately 200000 persons (14\% of the population 15-49 years) were tested with 1165 newly diagnosed PLHIV, indicating that many of the estimated 1600 newly infected persons in 2018 were unaware of their status.

Conclusions. Critical policy initiatives are needed to reduce barriers to HIV services, ensure young persons have access to condoms and contraceptives, affirm the rights of the marginalized, reduce stigma and discrimination, and introduce pre-exposure prophylaxis. While HIV spread in Jamaica has slowed, the UNAIDS Fast Track goals are lagging. The HIV program must be strengthened to effectively control the epidemic.

Keywords $\quad$ HIV infections; vulnerable populations; sexual behavior; Jamaica

Jamaica has both a generalized and a concentrated epidemic with an estimated adult HIV prevalence of 1.5\% in 1996 (1), $1.6 \%$ in 2007 (2) and 1.8\% in 2017 (3). Jamaica took a proactive approach to the HIV epidemic and established an active multi-sectoral response led by the Ministry of Health $(1,4)$. A public access antiretroviral treatment (ART) program was introduced in September 2004 and contributed to a significant decrease in HIV related deaths $(1,5)$. While the Government of Jamaica has committed to the UNAIDS Fast Track strategy for ending the AIDS epidemic as a public health problem by 2030 (6) much remains to be done to meet these ambitious goals. Preparation of a new National HIV Strategic Plan 2020-2025

\footnotetext{
1 The University of the West Indies, Mona, Kingston, Jamaica $\triangle$ J. Peter Figueroa, peter.figueroa10@gmail.com
}

provided an opportunity to review the HIV epidemic and response in Jamaica. The objective of the paper was to assess the status of the HIV epidemic and program implementation in Jamaica while identifying insights and strategies that may help guide Jamaica, and other small countries with limited resources, to accelerate progress towards effective HIV control.

\section{METHODS}

Three of the authors (JPF, JPD, AB) prepared the National HIV Strategic Plan 2020-2025 between April and December 2019 guided by a committee of key leaders of the HIV response,

\footnotetext{
2 Ministry of Health and Wellness, Kingston, Jamaica
} 
representatives of the Joint United Nations Program on HIV and AIDS (UNAIDS) and the Pan American Health Organization (PAHO), chaired by the Senior Medical Officer HIV/STI/ TB in the Ministry of Health and Wellness (NS). Approximately 30 key stakeholders, chaired by the Permanent Secretary in the Ministry of Health and Wellness, met monthly to review and critique the work.

Selected core indicators from the UNAIDS Global AIDS Monitoring Framework and Jamaica's monitoring and evaluation (M\&E) framework were used to assess the status of the HIV epidemic and program implementation in Jamaica (7). Main data sources and indicators for vulnerable populations are summarized in table 1. Estimates of persons living with HIV (PLHIV) in Jamaica were based on UNAIDS models using Ministry of Health data and surveys conducted in Jamaica. We reviewed national HIV surveillance reports of the Ministry of Health, reports of the ART information system managed by the national HIV team, UNAIDS Spectrum reports 2018 and 2019, HIV programmatic data and reports, program reviews, and numerous unpublished consultant and stakeholder reports and surveys as well as published papers on HIV/AIDS in Jamaica that were available on PubMed. Unstructured interviews were conducted to gain insights into the extent of program implementation including barriers and lessons learnt. Persons interviewed included government officials, HIV program staff in the Ministry and Health Regions, representatives of civil society and UN agencies.

Ethical approval was not required because the HIV program review used documentation and consultations without conducting any surveys of human subjects.

\section{RESULTS}

HIV prevalence among adults in Jamaica was 1.5\% in 2018 with an estimated 32617 PLHIV (8) (Table 2). As many as 5293 PLHIV (16.2\%) may be unaware of their HIV status. Approximately 27324 persons (83.8\%) have been diagnosed with $\mathrm{HIV}$ and most of them were linked to medical care (Figure 1).
TABLE 2. Summary of persons living with HIV in Jamaica as of December 2018

\begin{tabular}{lrc}
\multicolumn{1}{c}{ Indicator } & $\begin{array}{c}\text { Number of } \\
\text { persons }\end{array}$ & Percentage \\
\hline Persons living with HIV (PLHIV) in Jamaica & 32617 & \\
No. of PLHIV diagnosed & 27324 & $83.8 \%{ }^{*}$ \\
No. of persons newly HIV infected in 2018 & 1600 & \\
No. of persons newly diagnosed in 2018 & 1165 & \\
PLHIV unaware of their HIV status & 5293 & $16.2 \%^{*}$ \\
PLHIV diagnosed and lost to care & 14068 & $43.1 \%^{*}$ \\
PLHIV on antiretroviral treatment & 12711 & $39.0 \%^{*}$ \\
PLHIV virally suppressed & 7859 & $61.8 \%^{* *}$ \\
\hline
\end{tabular}

* \% of PLHIV in Jamaica; ** \% of PLHIV on antiretroviral treatment

Source: Compiled by the authors from UNAIDS Spectrum report 2019. Ministry of Health and Wellness HIV/AIDS Source: Compiled by the authors from UNAIDS Spectrum report 2019, Ministry of Health and Wellness HIV/AIDS Ministry of Health and Wellness.

However, 14069 of these persons have been lost to care and may not be on treatment. As of December 2018, 12711 (39.0\%) of all PLHIV or $46.5 \%$ of those aware of their status) were on ART in the public health sector. An estimated $61.8 \%$ of these persons were virally suppressed. In sum, with respect to the UNAIDS 90-90-90 targets (90\% of PLHIV aware of their status, $90 \%$ of those aware of their status on treatment, $90 \%$ of those on treatment virally suppressed) (5) Jamaica was at 84-47-62 as of December 2018.

Although 1600 persons were estimated to be newly HIV infected in Jamaica in 2018 (8) there were only 1165 newly diagnosed cases $(72.8 \%)$ reported by the Ministry of Health's surveillance system. This suggests that at least one quarter $(27.2 \%)$ of newly infected persons in 2018 were unaware of their status, and probably many more, because some of those newly diagnosed and reported in 2018 would have been infected before 2018. Of those cases newly reported in 2018, $47 \%$ were females and $53 \%$ were males; $14 \%$ were reported late, either as AIDS (9\%) or an AIDS death (5\%). HIV / AIDS case reports

TABLE 1. Main data sources for sub-populations in Jamaica

\begin{tabular}{|c|c|c|c|}
\hline Sub-populations & Indicators & Data Source (Years) & References \\
\hline MSM & $\begin{array}{l}\text { HIV prevalence } \\
\text { Condom use at last sex } \\
\text { HIV testing within the last } 12 \text { months }\end{array}$ & $\begin{array}{l}\text { Second generation surveillance } \\
(1988,2007,2011,2017)\end{array}$ & $9,10,12,13$ \\
\hline Female SW & $\begin{array}{l}\text { HIV prevalence } \\
\text { Condom use at last sex with client } \\
\text { HIV testing within the last } 12 \text { months }\end{array}$ & $\begin{array}{l}\text { Second generation surveillance } \\
(1990,1997,2005,2008,2011, \\
2014,2017)\end{array}$ & $14,15,16,17,18$ \\
\hline Transgender women & $\begin{array}{l}\text { HIV prevalence } \\
\text { Condom use at last sex } \\
\text { HIV testing within the last } 12 \text { months }\end{array}$ & $\begin{array}{l}\text { Second generation surveillance } \\
(2007,2011,2017)\end{array}$ & 9,10 \\
\hline ANC attendees & HIV prevalence & ANC sentinel surveillance 1986 - 2017 & $1,4,20$ \\
\hline STD clinic attendees & HIV prevalence & $\begin{array}{l}\text { STD clinic sentinel surveillance } \\
1986-2017\end{array}$ & $1,4,20$ \\
\hline PLHIV & $\begin{array}{l}\text { Number of persons living with HIV } \\
\text { Number of new HIV infections } \\
\text { Number of HIV-related deaths }\end{array}$ & $\begin{array}{l}\text { UNAIDS spectrum software estimates, } \\
\text { HIV/AIDS surveillance system }\end{array}$ & $1,2,3,4,7,8$ \\
\hline $\begin{array}{l}\text { High-risk heterosexual men } \\
\text { and women }\end{array}$ & $\begin{array}{l}\text { Median age of first sex } \\
\text { Condom use at last sex } \\
\text { Multiple partnership }\end{array}$ & KAB survey (2017) & $28,29,30,32$ \\
\hline
\end{tabular}
MSM, men who have sex with men; SW, sex worker; ANC, antenatal clinic; STD, sexually transmitted diseases; PLHIV, people living with HIV; KAP, Knowledge, Attitudes and Behavior
Source: compiled by the authors 
peaked at 2187 in 2008, declined to 1101 in 2015, increased to 1383 in 2017 and were 1165 in 2018 (Figure 2). There were only 179 HIV related deaths reported in 2018.

Among persons reported to the surveillance system as newly diagnosed HIV cases in 2018,63\% lived in 4 of the 14 parishes in Jamaica (Kingston \& St Andrew, St James and St Catherine). Heterosexual men with a high-risk profile (multiple sex partners, having a sexually transmitted infection (STI) or being a client of a sex worker) accounted for $43 \%$ of all newly diagnosed HIV infections. One third (32\%) of newly diagnosed HIV cases were women who had no obvious risk and therefore became infected because of the risk behaviour of their male sexual partner (1). $13 \%$ of new HIV infections were among women of high risk (multiple sex partners, STIs) and 2\% among female sex workers. $10 \%$ of all new HIV infections reported in 2018 were among men who have sex with men (MSM). This figure is likely to be an underestimate given the high HIV prevalence among MSM (approximately 30\%) $(9,10)$ and the stigma associated with homosexuality in Jamaica (1). Contact tracing of newly diagnosed cases in 2018 identified only 1.5 sex partners compared to 2.5 in 1995 (4).

Jamaica has had both a generalized and a concentrated epidemic that is somewhat different to the main HIV epidemic patterns described internationally $(1,11)$. Historically, $80 \%$ of

FIGURE 1. HIV testing and treatment cascade, Jamaica, 2018

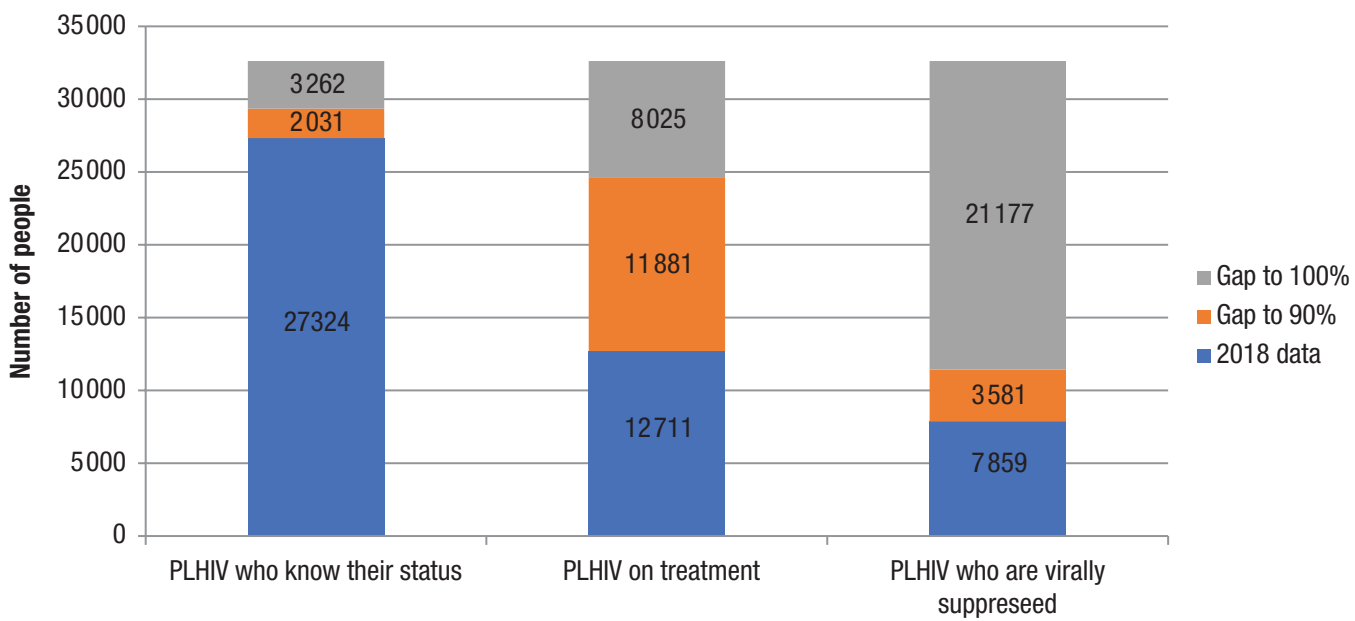

Source: UNAIDS Spectrum report 2019; Ministry of Health HIV/AIDS treatment database

FIGURE 2. No. of HIV cases, AIDS cases and AIDS deaths reported in Jamaica 1982-2018 Number of Cases Reported by Disease Stage 2500

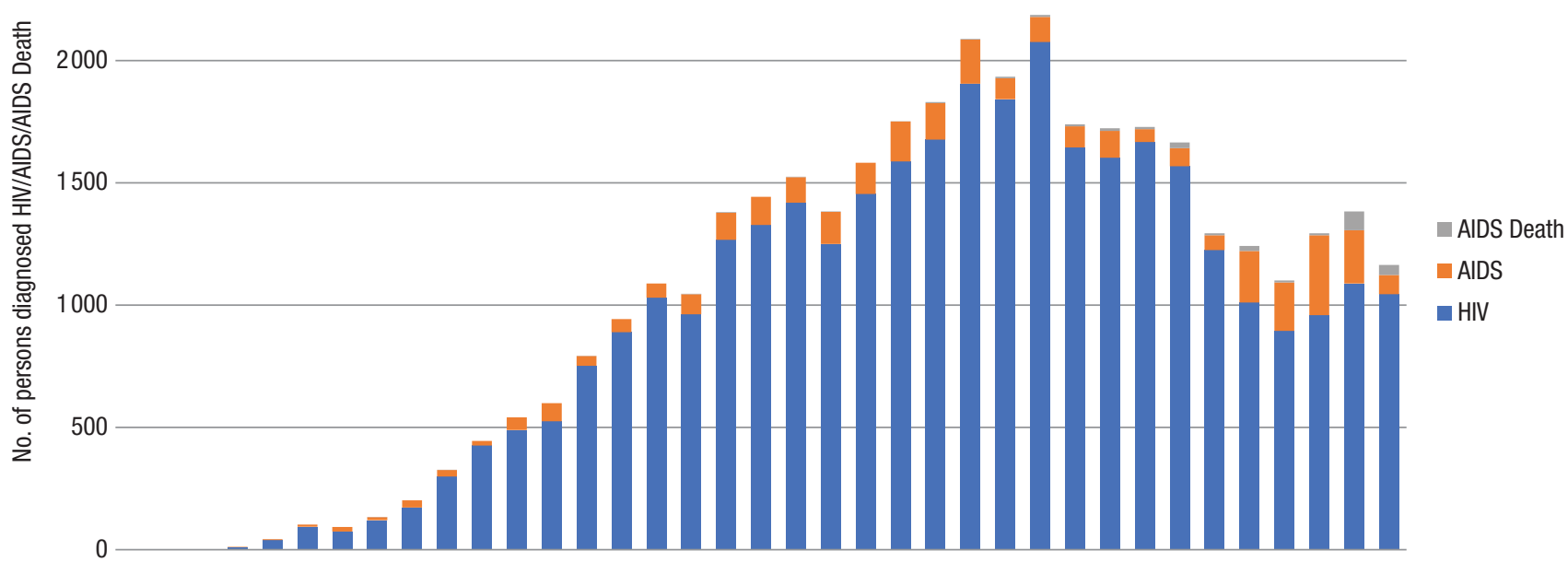

。 
HIV cases reported to the surveillance system had multiple sexual partners, $50 \%$ reported ever having a STI, $20 \%$ participated in commercial sex and $20 \%$, mostly women, reported no obvious risk. Crack/cocaine use was reported by $5 \%$ of HIV cases initially while injecting drug use was rare. A mode of transmission study conducted in 2012 showed an increase in the proportion of MSM among reported HIV cases from 10\% to $32 \%$ (11). Associated with this was an increase in the proportion of HIV cases among women who were partners of MSM from $3 \%$ to $7.2 \%$. There was a reduction in the proportion of heterosexuals at high risk from $67 \%$ to $28 \%$ and an increase of heterosexuals at low risk (mostly women) from $20 \%$ to $30 \%$ (11).

\section{Men who have sex with men}

HIV prevalence among MSM in Jamaica was estimated to be 9.6\% in 1988 (12) (Table 3), 32.3\% in 2007 (13), 31.4\% in 2011 (9) and $29.6 \%$ in 2017 (10). More than 50\% of MSM report also having sex with women. HIV prevalence among transgender women was 52.9\% in 2011 (9) and 51.0\% in 2017 (10). Between the 2007 and 2011 surveys the HIV incidence rate was estimated to be 6.7 cases /100 person years (95\% CI 3.74,12.19) (9). HIV prevalence among MSM increased significantly with age (24.2\% among $16-24$ years, $42.0 \%$ among those $25+$ years) and the number of adverse life events (test for trend $\mathrm{P}<0.001$ ) (9). Significant risk factors for HIV infection were identifying as a transgender woman, having a STI, high-risk sex and participation in both receptive and insertive anal intercourse $(9,10)$.

\section{Female sex workers}

HIV prevalence among female sex workers (SW) was estimated to be $12 \%$ in $1990,9 \%$ in 1997 and $2005,4.9 \%$ in 2008, $5.4 \%$ in 2011 and $3.2 \%$ in 2014 (14-17). A survey in 2017 estimated an HIV prevalence of $2 \%$ (18). However, the number of SW who refused to participate was not reported, and HIV prevalence would be higher if only a few HIV positive SW failed to participate in the survey. While reported condom use is very high among SW with their clients, a condom is not always used with a regular client and frequently not used with the main partner of SW (19). The high prevalence of other STI among SW is consistent with the failure to use the condom at all times. Nevertheless, condom use with clients of SW is the norm (19).

\section{Other populations}

HIV prevalence among public STI clinics attendees increased from $2.5 \%$ in 1986 to peak at $7.1 \%$ in 1999 , declined to $4.6 \%$ among males and $2 \%$ among females in 2014, and increased to $7.3 \%$ among males and 3\% among females in $2017(4.6 \%)$ (20). HIV prevalence among public antenatal clinic attendees increased from 1\% in 1990 to a peak of $2 \%$ in 1996 and declined to $0.9 \%$ in 2017 (20). Prevalence of syphilis among pregnant women was $1.2 \%$ in 2016 and $1.0 \%$ in 2017 (20). HIV prevalence among prison inmates was 3.3\% in 2003, 2.5\% in 2013 and 2017, and $6.9 \%$ in $2019(21,22)$. HIV prevalence among homeless persons increased from $8.8 \%$ in 2009 to $13.8 \%$ in 2015 (males $11.6 \%$, females 26.7\%) (23). During 2018, approximately 200000 persons were tested (14\% of adults aged $15-49$ years) and 235000 HIV tests done resulted in 3802 positive tests and 1165 newly diagnosed PLHIV. Some persons were tested more than once and all persons testing positive were advised to repeat their test. $35304 \mathrm{HIV}$ tests were done in hospitals representing one third of all admissions.

\section{DISCUSSION}

The National HIV Program has contributed significantly to slowing the spread of HIV in Jamaica. Mortality and morbidity due to HIV has been considerably reduced and thousands of HIV infections averted $(1,11)$. HIV prevalence among female sex workers has been reduced significantly because of outreach targeted intervention programs for three decades so SW are socialized and supported to use condoms. Mother to child transmission of HIV and congenital syphilis are on the verge of elimination (24).

Despite these achievements, HIV rates remain very high among MSM and transgender women while stigma, discrimination and hostility towards them remain strong. Gender inequity, inter-personal violence, high-risk sexual behaviour, and prevalence of other STI all continue to contribute to HIV spread. The number of persons becoming newly HIV infected each year is far too high (1 600 in 2018). The incidence/prevalence ratio in Jamaica in 2018 was estimated to be $5.0 \%$ compared with $3.9 \%$ in the Caribbean and $4.4 \%$ globally in $2019(25,26)$. In order to achieve epidemic control in Jamaica, the number of new HIV infections annually must be reduced to less than 1000 (ratio of $3.0 \%$ ) and preferably lower than 600 (25).

TABLE 3. HIV prevalence and population size estimates of subgroups in Jamaica, 1988-2019

\begin{tabular}{|c|c|c|c|c|c|}
\hline Subgroup & 1990 & 2000 & 2010 & 2017 & $\begin{array}{c}\text { Estimated } \\
\text { population size }\end{array}$ \\
\hline Transgender women & & & $52.9 \%$ & $51.0 \%$ & 3841 \\
\hline Inmates & & $3.3 \%$ & $2.5 \%$ & $6.9 \%$ & 3700 \\
\hline Homeless & & & $8.8 \%$ & $13.8 \%$ & 935 \\
\hline STD clinic attendees & $2.5 \%$ & $7.1 \%$ & $\begin{array}{l}\text { Male } 4.6 \% \\
\text { Female } 2 \%\end{array}$ & $\begin{array}{l}\text { Male } 7.3 \% \\
\text { Female 3\% }\end{array}$ & - \\
\hline
\end{tabular}


Jamaica needs to improve its performance with respect to the UNAIDS 90-90-90 targets (84-47-62 as of December 2018). Only $39 \%$ of PLHIV in Jamaica are documented as being on treatment though the actual proportion may be nearly $60 \%$ if we factor in unreported HIV related deaths, migration and persons treated by private doctors. Only $62 \%$ of PLHIV on treatment were virally suppressed in 2018. The number of PLHIV being treated in the private health sector was thought to be 500. Some (5\%-10\%) of persons aware of their status may have migrated. The 179 HIV related deaths reported in 2018 were an underestimate because many family members ask doctors not to write HIV or AIDS on death certificates. A "return to care" campaign conducted at selected treatment sites in 2019 found that 1016 (20\%) of the 5189 resolved cases were unreported deaths (27). However, many PLHIV would still not be on treatment which is difficult to understand despite long waiting times and other challenges faced in accessing ART in the public sector.

In Jamaica many social and cultural factors contribute to the spread of HIV (28). Sex begins at an early age. The median age of first sex for boys decreased from 16.5 years in 1996 to 15 years in 2017, and for girls from 18.2 years in 1996 to 17 years in 2017 $(29,30) .42 \%$ of boys and $12 \%$ of girls aged $15-24$ years reported initiating sex before 15 years of age although the legal age of consent is 16 years. Most of this sexual activity is with their peers and therefore should not be criminalized as statutory rape. However, many adolescent girls, and some boys, are having relationships with much older persons. These relationships usually have a transactional aspect that may include financial support by the older man to the mother of the adolescent. Girls in these relationships are at risk of sexual abuse, pregnancy, HIV and other STIs. A survey of 230 inner city youth aged $16-$ 19 years in 2013 found that $31 \%$ of the boys and $45 \%$ of the girls reported one or more STI (Figueroa et al., unpublished). Teenage pregnancy remains common in Jamaica and access to condoms and contraceptives is limited for young persons (31).

Population-based surveys have shown that $50 \%$ or more men and $12 \%-15 \%$ of women report having two or more sexual partners in the past year; in $201748.9 \%$ of men and $13.8 \%$ of women $(1,4,30,32)$. Women tend to under-report sexual partners due to social desirability bias. Focus groups suggest that $30 \%-$ $40 \%$ of women may have more than one sex partner in the past year. Among persons 15 - 49 years reporting multiple sex partners in the past 12 months $63.7 \%$ of men and $40.9 \%$ of women said they used a condom at last sex. Among persons aged $15-$ 24 years $80.1 \%$ of males and $65.2 \%$ of females reported condom use at last sex with a non-regular partner (30). Transactional sex was reported by $45.4 \%$ of men and $16.5 \%$ of women in 2017 compared with $53.8 \%$ of men and $23.6 \%$ of women in 2012 (30).

\section{Love and trust paradigm}

Condom use tends to be low with one's main partner in Jamaica due to the "love and trust" paradigm (1). There is strong belief and expectation that condoms should not be needed in the main partnership because in the ideal relationship one is special, and the intimacy should not be disturbed by condom use. If the man has other sexual partners the expectation is that he should use a condom with the other partners. If either partner suggests the use of a condom it may imply that your partner or you were not faithful. This may lead to suspicions that undermine the special relationship. In promoting consistent condom use this paradigm must be taken into account. Condom use during casual sex, with a non-regular sex partner or during commercial sex is generally accepted as desirable, normative behaviour though many persons do not practice it consistently.

\section{HIV stigma remains strong}

Stigma and discrimination associated with HIV is considerably less than what it was 3 decades ago but stigma remains strong $(33,34)$. Many PLHIV have a sense of shame and find it difficult to disclose their status to their family or sexual partner. Within the health sector discrimination against PLHIV has declined but some health staff breach confidentiality by gossiping (34). Stigma associated with homosexuality continues to be widespread $(9,11,13)$. The anti-buggery law is a reminder to MSM that they are rejected by society and criminalized. The rejection often induces shame, conflict, low self-esteem and risk taking. MSM of lower socio-economic status are more vulnerable and boys may be chased from their home and become homeless and subject to sexual abuse, transactional sex or forced into commercial sex. MSM who are of low literacy or experience adverse life events such as violence, jail or homelessness are at significantly higher risk of HIV (9). Some MSM live in fear or disguise their sexuality by having a relationship with a woman or pretending to be straight.

Most heterosexual men living with HIV fear that they will be seen as MSM and treated as such. The pervasive stigma and discrimination associated with HIV and especially homosexuality drives the HIV epidemic underground and contributes to its further spread $(1,11)$. Some persons at risk, especially men, are fearful of doing an HIV test in case they find out that they are HIV positive. PLHIV are fearful to inform their sexual partners of their status thus increasing the risk of transmission although most PLHIV do not wish anyone to become HIV infected and certainly not someone they love.

In sum, the main factors driving the HIV epidemic in Jamaica include high-risk behaviour of many heterosexual men, high HIV prevalence among MSM, half of whom are bisexual, which acts as a bridge for HIV into the general population. Most men are uncircumcised, STIs are common and the youth are not empowered with safe sex skills. Gender inequity and some cultural factors contribute to risky sexual behaviour while stigma associated with HIV and homosexuality are a barrier to services. Failure to decisively affirm the rights of MSM, sex workers and other marginalized groups and combat stigma and discrimination are a problem.

\section{Limitations}

This paper does not attempt a comprehensive review of all aspects of the HIV response such as governance, finance, human resources, and M\&E. The authors had to depend on Ministry of Health information systems and reports, which had important information gaps and inconsistencies. Sexual orientation and risk factors were often missing from HIV case reports. Several recent surveys were not published and therefore not subject to peer review. It was not possible to examine HIV reporting trends or to estimate the level of under reporting. The authors found inconsistencies in UNAIDS Spectrum report 2018 resulting in an over estimate of PLHIV in Jamaica. The authors used the revised estimates in the UNAIDS 2019 report in this paper. 


\section{Lessons learned}

Despite the limitations, the authors identify several lessons. Provider initiated testing in hospitals, of persons with STI, and sexual contacts of PLHIV are important ways of identifying new HIV cases. Targeted outreach prevention interventions can achieve a significant decrease in HIV prevalence among SW. While it is feasible to sustain fairly high condom use among persons having sex with a SW or non-regular sexual partner, successful interventions among MSM are difficult in a context where homosexuality is criminalised and stigma is strong. Evidence indicates a need to introduce pre-exposure prophylaxis to prevent HIV among MSM (35). Successful litigation will be required to ensure that governments decriminalise same sex behaviour. Sex education and access to condoms and contraceptives for youth are essential through multiple approaches including peers, school, outreach and social media. Weaknesses in HIV reporting and information systems must be improved in order to better monitor progress.

\section{Addressing the challenges}

The National HIV Program needs to strengthen its leadership and management of the response, articulate a clear vision and strategy, communicate it effectively to the public and better motivate, train and supervise the staff to achieve the goal of ending the epidemic as a public health problem. HIV testing must be expanded in public and private health sectors, including provider initiated and targeted outreach testing. Risk reduction conversations to improve risk perception and consistent condom use must be an integral part of HIV testing. Persons testing HIV positive need to be placed on medication within 24 hours and no later than 7 days. HIV treatment sites in the public sector need to be more efficient and sensitive to patient needs and concerns. Contact tracing needs to be improved and the cadre of contact investigators expanded. Pre-exposure prophylaxis (PrEP) for HIV discordant couples and persons at high risk needs to be introduced without further delay (35).

Critical policy initiatives are needed to help change social norms and reduce barriers to HIV services. Young persons need age appropriate sex education and safe sex skills and access to counseling, condoms and contraceptives. The government needs to introduce a "close in age" clause in the Offenses against the Person Act so that adolescents of a similar age (within 4 years) having sex with a minor are not automatically considered to have committed statutory rape. Health professionals must have the right to judge when they need to report that a minor is being sexually abused. It is important not to criminalize HIV transmission because this will discourage persons from doing an HIV test and drive the epidemic underground resulting in further HIV spread. Measures must be taken to reduce stigma and discrimination and affirm the human rights of PLHIV, MSM and marginalized groups. The Occupational Health \& Safety Act, which prohibits discrimination on the basis of health, needs to be promulgated. The government is unlikely to decriminalize buggery/homosexuality unless there is successful litigation. Community and civil society advocates must continue to educate the public and strive for these policies with the support of HIV program leaders.

\section{Conclusions}

This review suggests that the HIV Program is lagging with respect to achieving the UNAIDS Fast Track goals. While there have been important gains such as the significant decrease in HIV prevalence among SW and reduced stigma and discrimination, government leaders are reluctant to effect bold policy changes that would greatly facilitate further progress. Therefore, the onus falls on HIV Program leaders to implement quality services more effectively including introducing PrEP. We are confident that with the support of the government, and commitment of all stakeholders and partners, a strengthened HIV Program can achieve HIV epidemic control by 2030.

Authors' contributions. JPF drafted the manuscript. All authors participated in the review of HIV in Jamaica, contributed to revision of the manuscript, and approved it.

Acknowledgements. The authors thank the staff of the Ministry of Health and Wellness, and all stakeholders and partners, who facilitated access to HIV data and documents and participated in discussions related to the preparation of the Jamaica HIV National Strategic Plan 2020-2025.

Conflicts of interests. The authors disclose that in the past JPF was the Director, and JPD and AB were senior staff, of the National HIV program in the Ministry of Health, Jamaica. NS was the Senior Medical Officer HIV /STI/TB during 2019 and is employed to the Ministry of Health and Wellness. JPF, JPD and $A B$ were hired as technical consultants to prepare the National HIV Strategic Plan 2020-2025.

Disclaimer. Authors hold sole responsibility for the views expressed in the manuscript, which may not necessarily reflect the opinion or policy of the PAJPH and/or PAHO.

\section{REFERENCES}

1. Figueroa JP, Duncan J, Byfield L, Harvey K, Gebre Y, HyltonKong $\mathrm{T}$, et al. A comprehensive approach to the HIV/AIDS epidemic in Jamaica: review of the past 20 years. West Indian Med J. 2008;57:562-576.

2. Joint United Nations Program on HIV/AIDS (UNAIDS)/World Health Organization (WHO). AIDS epidemic update. Geneva: WHO; 2007.

3. UNAIDS Spectrum report. Geneva: UNAIDS; 2018.
4. Figueroa JP, Brathwaite AR, Wedderburn M, Ward E, Lewis-Bell, Amon JJ, et al. Is HIV/STD Control in Jamaica making a difference? AIDS. 1998;12(Suppl.2):S89-S98.

5. Ministry of Health \& Wellness HIV/STI/TB Unit. HIV Fact Sheet Jamaica. Kingston, 2019.

6. UNAIDS. Fast Track - Ending the AIDS epidemic by 2030. Geneva: UNAIDS; 2014. Available at: https:/ / www.unaids.org/en/resources/ documents/2014/JC2686_WAD2014report Accessed 31 January 2020. 
7. UNAIDS Global AIDS Monitoring Framework 2017. Geneva: UNAIDS; 2017.

8. UNAIDS Spectrum report (revised estimates). Geneva: UNAIDS; 2019.

9. Figueroa JP, Jones Cooper C, Edwards JK, Byfield L, Eastman S, Hobbs MM, et al. Understanding the High Prevalence of HIV and other STI among Socio-economically Vulnerable MSM in Jamaica. PLoS One. 2015 Feb 6;10(2):e0117686. doi: 10.1371/journal. pone.0117686.

10. Ministry of Health and Wellness. The 876 Study: Biological and Behavioural Survey with Population Size Estimation among MSM in Jamaica. Kingston, 2018. (Unpublished report).

11. Figueroa JP. Review of HIV in the Caribbean: Significant Progress and Outstanding Challenges. Curr HIV/AIDS Rep. 2014. DOI 10.1007/s11904-014-0199-7.

12. Murphy EL, Gibbs WN, Figueroa JP, Bain B, La Grenade L, Cranston $B$, et al. Human immuno-deficiency virus and human T-Lymphotropic virus Type I infection among homosexual men in Kingston, Jamaica. J Acquir Immune Defic Syndr. 1988;1:143-149.

13. Figueroa JP, Weir SS, Jones Cooper C, Byfield L, Hobbs M, Mcknight I, et al. High HIV Prevalence among MSM in Jamaica is associated with Social Vulnerability and other Sexually Transmitted Infections. West Indian Med J. 2013;62(4):282-7.

14. Hope Enterprises Ltd. HIV second generation surveillance: Behavioural surveillance survey among female sex workers. Jamaica Ministry of Health \& PAHO; 2005.

15. Duncan J, Gebre Y, Grant Y, Wedderburn M, Byfield L, Bourne D, et al. HIV prevalence and related behaviours among sex workers in Jamaica. Sex Transm Dis. 8 Jan 2010;37(5):306-10. doi: 10.1097/ OLQ.0b013e3181c6e851.

16. Duncan J, Weir SS, Byfield L, Jones Cooper C, Jarrett S, Figueroa JP. STI Prevalence and Risk Behaviours among Establishment-based Sex Workers and Street-based Sex Workers in Jamaica. J AIDS Clin Res. 2014;5:320. http:/ /dx.doi.org/10.4172/2155-6113.1000320

17. Weir SS, Figueroa JP, Scott M, Byfield L, Jones Cooper C, Hobbs MC. Reaching key populations through key venues: insights from the Jamaica HIV prevention program. PLOS One. 2018 Nov26;13(11):e0206962. doi: 10.1371/journal.pone.0206962.

18. Skyers N, Scott Thomas M, Bailey A, Campbell A. The $4^{\text {th }}(2017)$ Generation Surveillance of Commercial Sex Workers Female Patrons and Workers of Sites where Persons Meet Sex Partners or Participate in Sexual Activity in Jamaica. Kingston, 2017. (Unpublished report).

19. Bailey AE, Figueroa JP. Agency, Lapse in Condom use and Relationship Intimacy among Female Sex Workers in Jamaica. Cult Health Sex. 2017;20:5,531-544. doi: 10.1080/13691058.2017.1360944

20. Ministry of Health and Wellness. National HIV/STI Programme HIV sentinel surveillance report 2017. Kingston: MHW; 2017.

21. Andrinopoulos K, Kerrigan D, Figueroa JP, Reese R, Gaydos C, Bennett L, et al. Establishment of an HIV/sexually transmitted disease programme and prevalence of infection among incarcerated men in Jamaica. Inter J STD AIDS. 2010;21:114-9.

22. Bailey A. Bio-Behavioral Surveillance Survey of Inmates in Jamaica. March 2019.

23. Skyers N, Jarrett S, McFarland W, Cole D, Atkinson U. HIV Risk and Gender in Jamaica's Homeless Population. AIDS Behav. 2018;22:65-69.

24. Ministry of Health and Wellness. Jamaica Global AIDS Monitoring Report 2019. Kingston: MHW; 2019.

25. UNAIDSSciencePanel.Making theend ofAIDSreal:Consensusbuilding on what we mean by "epidemic control". Geneva: UNAIDS; 2017. https://www.unaids.org/sites/default/files/media_asset/glion_ oct2017_meeting_report_en.pdf Accessed 31 January 2020.

26. UNAIDS. 2020 Global AIDS Update - Seizing the moment - Tackling entrenched inequalities to end epidemics. Geneva: UNAIDS; 2020. https://www.unaids.org/en/resources/documents/2020/globalaids-report Accessed 12 July 2020.

27. PEPFAR. Caribbean Regional Program Regional Operational Plan Jamaica Strategy. Kingston, 2019. (Unpublished report).

28. Figueroa JP. Understanding Sexual Behaviour in Jamaica. In Levy $\mathrm{H}$, ed. "The African-Caribbean Worldview and the Making of Caribbean Society". Kingston: University of the West Indies Press; 2009.

29. Hope Enterprises Ltd. Findings of the 1996 Knowledge, Attitude and Practice Study on AIDS and STDs in Jamaica. Kingston; 1997.

30. Hope Caribbean Co. Ltd. and Ministry of Health. 2017 HIV/AIDS Knowledge, Attitudes and Behavior Survey, Jamaica. Kingston; 2017.

31. UNFPA Country Brief Jamaica. 9 September 2017. Available from: https://caribbean.unfpa.org/en/news/country-brief-jamaica Accessed 31 January 2020.

32. Figueroa JP, Ward E, Walters C, Ashley D, Wilks R. High Risk Behaviour among Adults in Jamaica. West Indian Med J. 2005;54(1):70-6.

33. Jamaica Network of Seropositives, UNAIDS. The People Living with HIV Stigma Index: Jamaica. Kingston, 2015. (Unpublished report).

34. Health Policy Plus. Stigma and Discrimination in Selected Health Facilities in Jamaica. Kingston, 2018. (Unpublished report).

35. US Preventive Services Task Force. Preexposure Prophylaxis for the Prevention of HIV Infection: US Preventive Services Task Force Recommendation Statement. JAMA. 2019;321(22):2203-13. doi:10.1001/ jama.2019.6390

Manuscript received on 21 May 2020. Revised version accepted for publication on 4 August 2020. 


\section{Epidemia de la infección por el VIH en Jamaica: necesidad de fortalecer el Programa Nacional contra el VIH}

RESUMEN Objetivos. Evaluar el estado de la epidemia de la infección por el VIH en Jamaica y de la ejecución programática, ydeterminar las estrategias para lograr un control eficaz de la infección por el VIH.

Métodos. La evaluación incluyó una revisión de los indicadores básicos del Marco de Vigilancia Mundial del ONUSIDA, un estudio teórico de informes programáticos y entrevistas no estructuradas a los interesados directos. Resultados. La prevalencia de la infección por el VIH en adultos en Jamaica fue del 1,5\% en el 2018, con unas 32617 personas infectadas y unas 27324 personas (83,8\%) con diagnóstico de infección por el VIH; 12711 personas $(39,0 \%$ del total de personas con infección por el $\mathrm{VIH}$, o el 46,5\% de las que conocían su estado) estaban bajo tratamiento antirretroviral en el sector de salud pública, y el 61,8\% de las personas con infección por el VIH que recibieron tratamiento antirretroviral alcanzó la supresión viral. La prevalencia de la infección por el VIH en hombres que tienen relaciones sexuales con hombres sigue siendo alta (31,4\% en el 2011, 29,6\% en el 2017), aunque ha descendido en las trabajadoras sexuales (12\% en 1990, 2\% en el 2017). En los últimos años, la prevalencia de la infección por el VIH en personas que acuden a centros públicos de atención de infecciones de transmisión sexual, presidiarios y personas sin hogar ha aumentado. En el 2018, aproximadamente 200000 personas (14\% de la población entre 15 y 49 años) se sometieron a la prueba de $\mathrm{VIH}$, de las cuales 1165 fueron diagnosticadas como personas recién infectadas por el HIV, lo cual indica que muchas de las 1600 personas recién infectadas en el 2018 desconocían su estado.

Conclusões. Se necesitan iniciativas políticas fundamentales para reducir los obstáculos que impiden el acceso a los servicios de atención de la infección por el VIH, asegurar que las personas jóvenes tengan acceso a preservativos y anticonceptivos, afirmar los derechos de las personas marginadas, reducir la estigmatización y la discriminación, e introducir la profilaxis previa a la exposición. Si bien la propagación de la infección por el VIH se ha desacelerado en Jamaica, el logro de los Objetivos de Respuesta Rápida del ONUSIDA está demorado. Debe fortalecerse el Programa contra el VIH para controlar eficazmente la epidemia.

Palabras clave Infecciones por VIH; poblaciones vulnerables; conducta sexual; Jamaica.

\section{A epidemia de HIV na Jamaica: a necessidade de fortalecer o Programa Nacional de HIV}

RESUMO

Objetivos. Avaliar a situação da epidemia de HIV e a implementação do Programa Nacional de HIV na Jamaica, identificando estratégias eficazes para controlar o HIV.

Métodos. A avaliação incluiu uma revisão dos indicadores-chave da Estrutura de Monitoramento Global do UNAIDS, uma revisão documental dos relatórios do programa e entrevistas não estruturadas com participantes. Resultados. A prevalência de infecção pelo HIV em adultos na Jamaica foi de 1,5\% em 2018. Estima-se que haja 32.617 pessoas vivendo com o HIV (PVHIV), das quais 27.324 (83,8\%) foram diagnosticadas; 12.711 (39,0\% de todas as PVHIV, e 46,5\% das que conhecem seu diagnóstico) estavam em terapia antirretroviral (TAR) no setor da saúde pública, e 61,8\% das PVHIV em ART alcançaram a supressão viral. A prevalência de HIV entre homens que fazem sexo com homens continua alta (31,4\% em 2011, 29,6\% em 2017), mas diminuiu entre mulheres profissionais do sexo (12\% em 1990, 2\% em 2017). A prevalência de HIV entre os pacientes que frequentam clínicas públicas de atenção a infecções sexualmente transmissíveis, presidiários e desabrigados tem aumentado nos últimos anos. No ano de 2018, aproximadamente 200.000 pessoas (14\% da população de 15 a 49 anos) foram testadas, sendo feitos 1.165 novos diagnósticos de infecção pelo HIV, o que indica que muitas das 1.600 pessoas recém-infectadas estimadas em 2018 não estavam cientes de sua infecção.

Conclusões. São necessárias iniciativas políticas essenciais para reduzir as barreiras no acesso aos serviços de HIV, assegurar que os jovens tenham acesso a preservativos e métodos contraceptivos, afirmar os direitos dos marginalizados, reduzir o estigma e a discriminação e introduzir a profilaxia pré-exposição. Embora a propagação do HIV na Jamaica tenha perdido velocidade, o progresso para alcançar as metas da estratégia Fast Track do UNAIDS tem sido lento. Para controlar a epidemia de forma eficaz, é preciso fortalecer o Programa Nacional de HIV.

Palavras-chave Infecções por HIV; populações vulneráveis; comportamento sexual; Jamaica. 